\title{
Quercetin Interferes in the Acetylcholinesterase Activity-Modulated by Tamoxifen in Brain of the Ovariectomized Rats
}

\author{
Carla Brugin Marek ${ }^{1 *}$, Ana Maria Itinose ${ }^{2}$, Queite Hirome Takemoto ${ }^{1}$, Adrieli Gorlin Toledo ${ }^{1}$ and Fernanda \\ Coleraus Silva ${ }^{1}$
}

${ }^{1}$ Laboratory of Cellular Toxicology, State University of Western Parana, Brazil

${ }^{2}$ Assistance Center in Toxicology (CEATOX), Hospital University of Western Parana, Brazil

Submission: November 25, 2016; Published: December 02, 2016

*Corresponding author: Carla Brugin Marek, Laboratory of Cellular Toxicology, State University of Western Parana, Rua Universitária 1619, 85819110, Cascavel PR, Brazil, Fax:+51 453321 5429; Email: carla.marek@unioeste.br

\begin{abstract}
This study investigated the influence of quercetin on the action of tamoxifen on the acetylcholinesterase in cerebellum, cortex and hippocampus in rat. Ovariectomized rats were treated with tamoxifen (5mg/Kg) and quercetin (2.5, 7.5, 22.5 or 67.5 mg/Kg) by gavage for 14 days. The results showed that tamoxifen modulates the cholinergic system, particularly the acetylcholinesterase activity, and that quercetin interferes in this modulation. The cerebellum was the least affected, while the cortex and hippocampus showed increase and decrease in the acetylcholinesterase activity, respectively. These data indicate that quercetin modulates the tamoxifen action and that this modulation is different in each brain region. We also observed that this interference is complex and region specific.
\end{abstract}

Keywords: Cholinergic system; Estrogen; Neurodegenerative disease

Abbreviations: SERM: Selective Estrogen Receptor Modulator

\section{Introduction}

The regulation of acetylcholine is crucial to ensure functionality of both the central and peripheral nervous systems, since it is related vital functions such as learning, memory and movement control [1]. Studies in animal models suggest that tamoxifen, a selective estrogen receptor modulator commonly prescribed hormonal treatment in postmenopausal women with breast cancer, increases the choline acetyltransferase mRNA expression in basal forebrain cholinergic neurons and is associated with declining cognitive decline [2]. Another compound in the cholinergic regulation is the flavonoid quercetin which increases synaptic transmission by inhibition acetylcholinesterase [3]. Recent study has shown that quercetin when coadministered with tamoxifen to enlarge the efficacy and minimize the side effects of tamoxifen $[4,5]$. In the present study, we examine the effect of quercetin on the cerebral acetylcholinesterase activity after modulation induced by tamoxifen.

Adult, female bilateral ovariectomized rats (Wistar), weighing $180-220 \mathrm{~g}$ were used in this study. To verify hormonal influence on the activity of acetylcholinesterase, not ovariectomized rats were used as control group. These animals were kept in cages under controlled room (temperature $22 \pm 2{ }^{\circ} \mathrm{C}$ and $12 \mathrm{hrs} \mathrm{light/dark} \mathrm{cycle)} \mathrm{with} \mathrm{water} \mathrm{and} \mathrm{standard} \mathrm{laboratory}$ diet (Nuvilab) ad libitum. Animal management was conducted according to the Brazilian regulations for the use of laboratory animals and the ethical principles for animal management. The tamoxifen $(5 \mathrm{mg} / \mathrm{Kg})$, quercetin $(2.5 ; 7.5 ; 22.5$ and $67.5 \mathrm{mg} / \mathrm{Kg})$ and vehicle (canola oil) were administered daily by gavage for 14 days. Ovariectomized rats were randomly divided into six groups each consisting of six animals. OVX Group $(1.0 \mathrm{~mL} / \mathrm{Kg}$ canola oil), OVXT Group (5.0mg/Kg tamoxifen), OVXTQ 2.5 Group (5.0 $\mathrm{mg} / \mathrm{Kg}$ tamoxifen $+2.5 \mathrm{mg} / \mathrm{Kg}$ quercetin), OVXTQ $_{7.5}$ Group $\left(5.0 \mathrm{mg} / \mathrm{Kg}\right.$ tamoxifen $+7.5 \mathrm{mg} / \mathrm{Kg}$ quercetin), OVXTQ $_{22.5}$ Group $\left(5.0 \mathrm{mg} / \mathrm{Kg}\right.$ tamoxifen $+22.5 \mathrm{mg} / \mathrm{Kg}$ quercetin) and $\mathrm{OVXTQ}_{67.5}$ Group $(5.0 \mathrm{mg} / \mathrm{Kg}$ tamoxifen $+67.5 \mathrm{mg} / \mathrm{Kg}$ quercetin). Six not ovariectomized rats were treated with vehicle $(1.0 \mathrm{~mL} / \mathrm{Kg}$ canola oil) corresponding control group (CON Group). After the treatment period, all rats were euthanized by decapitation under 


\section{Journal of Complementary Medicine \& Alternative Healthcare}

conditions overdose of ketamine and xylazine, then brains were removed and rapidly kept in cold $0.5 \%$ Triton X-100 Ringer's solution.

The cortex, hippocampus and cerebellum were carefully dissected by means of surgical scissors and tweezers. Homogenates were prepared by adaptation of the methodology described by Cimasoni (1966) [6]. Each region was prepared by tissue homogenization in buffered medium (pH 7.4) in the ratio $1: 3$ to obtain a final concentration of protein around $15 \mathrm{mg}$. The tissue was cut into small pieces and washed with a cold $\left(4{ }^{\circ} \mathrm{C}\right)$ Ringer's solution containing $0.5 \%$ Triton X-100. Homogenization was carried out in the same medium by means of glass homogenizers on ice. The homogenate was filtered through gauze and centrifuged at $536 \mathrm{~g}$ for $10 \mathrm{~min}$ followed by $4000 \mathrm{~g}$ for $10 \mathrm{~min}$. Their supernatant fraction was used for the determination of acetylcholinesterase activity. Protein content of the homogenate was measured using Folin-phenol reagent and bovine-serum albumin as a standard [7]. The results were expressed in mg of protein $/ \mathrm{mL}$. The acetylcholinesterase activity was measured by method of Ellman et al. [7] using acethylthiocoline as substrate. The reaction medium contained $0.25 \mathrm{mg}$ protein of the each region supernatant fraction, $100 \mathrm{mM}$ phosphate buffer $(\mathrm{pH} 8.0)$ and $0.5 \mathrm{~mm}$ DTNB. After determination of the blank, the reaction was started by addition of $0.5 \mathrm{~mm}$ acetylthiocoline iodide. The change in extinction was recorded at $405 \mathrm{~nm}$ for $60 \mathrm{~s}$. The specific enzyme activity was calculated as nmol of substrate hydrolyzed $/ \mathrm{min} / \mathrm{mg}$ protein. Data are expressed as mean \pm standard error o mean (SEM). The difference values between untreated group (OVXT) and animals treated with quercetin (OVXTQ) was evaluated using one-way analysis of variance (ANOVA) followed by Dunnet's test. The statistical significance of the differences between normal rats (CON) and untreated group (OVX) was evaluated by means of Student's t test. Differences were considered significant when the probability was $\mathrm{P}<0.05$.

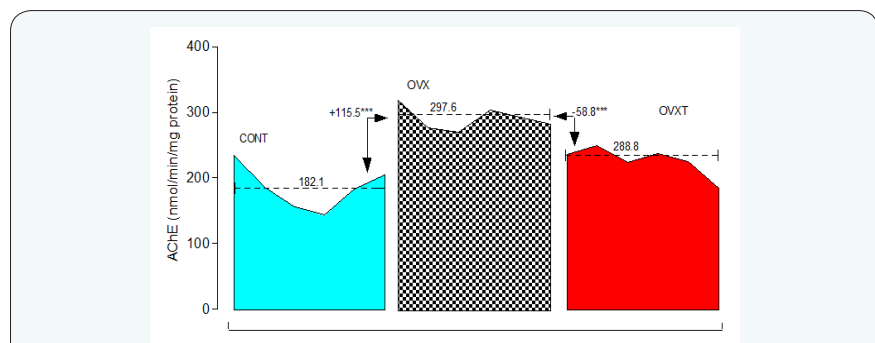

Figure 1: Effect of estrogen and tamoxifen on tota acetylcholinesterase activity in brain.

CONT - Rats no ovariectomized; OVX - rats ovariectomized; OVXT rats Ovariectomized treated with tamoxifen. Data represent the means \pm mean Standard errors of 6 animals.

*** $P<0.0001$

Estrogen deficiency significantly increased the total activity of acetylcholinesterase in brain in $115.5 \mathrm{nmol} / \mathrm{min} / \mathrm{mg}$ protein, from $182.1 \pm 13.2 \mathrm{nmol} / \mathrm{min} / \mathrm{mg}$ protein in not ovariectomized rats to $297.6 \pm 7.37 \mathrm{nmol} / \mathrm{min} / \mathrm{mg}$ protein in ovariectomized rats (Figure 1). The cortex showed less sensitivity to hormone deficiency, with an increase in the activity of $20.2 \mathrm{nmol} / \mathrm{min} /$ mg protein $(27.7 \% ; \mathrm{P}<0.05)$, followed by hippocampus with increase of $72.5 \mathrm{nmol} / \mathrm{min} / \mathrm{mg}$ protein $(81.9 \%$; $\mathrm{P}<0.01)$ and the cerebellum with increase of $22.8 \mathrm{nmol} / \mathrm{min} / \mathrm{mg}$ protein (110.7\%; $\mathrm{P}<0.01$ ), (Table 1). These findings confirmed that the estrogen deficiency significantly stimulates the activity of acetylcholinesterase and that this stimulus, although markedly higher in the cerebellum, is not regionalized reaching all regions of the brain (Figure 2) [8].

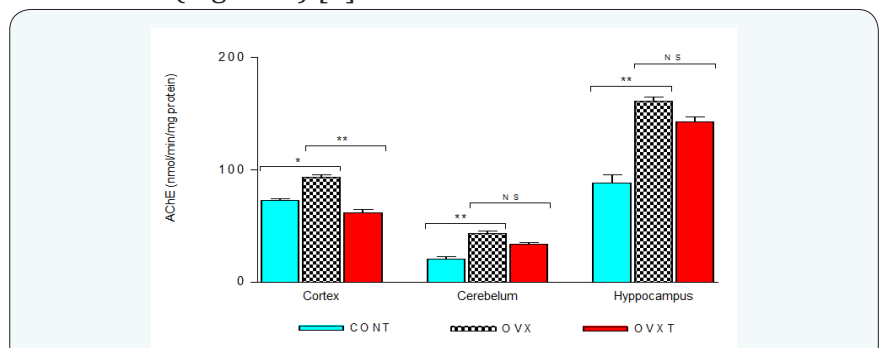

Figure 2: Effect of estrogen and tamoxifen on acetylcholinesterase activity in different regions of the brain.

CONT - rats no ovariectomized; OVX - rats ovariectomized; OVXT - rats ovariectomized treated with tamoxifen. Data represent the means \pm mean standard errors of 6 animals. ${ }^{*} \mathrm{P}<0.05$; ${ }^{* *} \mathrm{P}<$ 0.01; NS - No significative

Table 1: Acetylcholinesterase activity in different regions of brain CONT - rats no ovariectomized; OVX - rats ovariectomized; OVXT rats ovariectomized treated with tamoxifen. Data represent the means \pm mean standard errors of 6 animals

\begin{tabular}{|c|c|c|c|c|}
\hline \multicolumn{5}{|c|}{ Acetylcholinesterase Activity (nmol/min/mg protein) } \\
\hline $\begin{array}{c}\text { Treatment } \\
\text { Group }\end{array}$ & Cerebellum & Cortex & Hippocampus & $\begin{array}{c}\text { Total } \\
\text { Brain }\end{array}$ \\
\hline CONT & $20.6 \pm 4.26$ & $\begin{array}{c}73.0 \pm \\
2.83\end{array}$ & $88.5 \pm 14.0$ & $\begin{array}{c}182.1 \pm \\
13.2\end{array}$ \\
\hline OVX & $43.4 \pm 4.12^{* *}$ & $\begin{array}{c}93.2 \pm \\
5.18^{*}\end{array}$ & $161.0 \pm 7.97^{* *}$ & $\begin{array}{c}297.6 \pm \\
7.37^{* *}\end{array}$ \\
\hline OVXT & $34.0 \pm 2.80$ & $\begin{array}{c}61.8 \pm \\
6.04^{\ddagger *}\end{array}$ & $143.0 \pm 8.99$ & $\begin{array}{c}238.8 \pm \\
9.43^{\ddagger}\end{array}$ \\
\hline
\end{tabular}

${ }^{*} \mathrm{P}<0.05 ;{ }^{* *} \mathrm{P}<0.01$ refer significantly difference between OVX and CONT groups.

${ }^{t} \mathrm{P}<0.05 ;{ }^{\text {tt}} \mathrm{P}<0.01$ refer significantly difference between OVXT and OVX groups.

The cortex in ovariectomized rats was more sensitive to tamoxifen action with significant decrease in acetylcholinesterase activity (31.4 nmol/min/mg protein; 33.7\%; $\mathrm{P}<0.01$ ). The other regions have had slight decrease in activity, but without statistical significance, with $18.0 \mathrm{nmol} / \mathrm{min} / \mathrm{mg}$ protein and $9.4 \mathrm{nmol} / \mathrm{min} / \mathrm{mg}$ protein for hippocampus and cerebellum, respectively (Table $1 \&$ Figure 2 ). The results of the four different 


\section{Journal of Complementary Medicine \& Alternative Healthcare}

concentrations of quercetin used are summarized Table 2 . Except in the cerebellum where quercetin showed no significant change in the acetylcholinesterase activity ( $P>0.05)$, other regions were significantly affected. While there was evident cortex stimulation by the two highest concentrations $(22.5$ and $67.5 \mathrm{mg} / \mathrm{Kg}$ ), in the hippocampus was significant decrease in acetylcholinesterase activity of the animals treated with quercetin on dose of 7.5 and $22.5 \mathrm{mg} / \mathrm{Kg}$ (Figure 3). Actions of quercetin on acetylcholinesterase activity-modulated by tamoxifen can be seen in (Figure 4). The values represented were calculated by subtracting the activity of group tamoxifen plus quercetin $\left(\mathrm{OVXTQ}_{2.5-67.5}\right)$ of the OVXT group. The graph $4 \mathrm{~B}$ shows the effect of quercetin on the cortex follows an inverted U-sahpe curve. At the lowest dose $(2.5 \mathrm{mg} / \mathrm{Kg})$ there was no significant decrease $(16.3 \mathrm{nmol} / \mathrm{min} / \mathrm{mg}$ protein; $\mathrm{P}>0.05)$ on acetylcholinesterase activity, but from de dose of $7.5 \mathrm{mg} /$ $\mathrm{Kg}$, although also not significant, began a discrete increase in enzyme activity ( $9.1 \mathrm{nmol} / \mathrm{min} / \mathrm{mg}$ protein; $\mathrm{P}>0.05$ ), showing significant increase in activity at $22.5 \mathrm{mg} / \mathrm{Kg}$ dose $(35.4 \mathrm{nmol} /$ $\mathrm{min} / \mathrm{mg}$ protein; $\mathrm{P}<0.05)$. At the highest dose $(67.5 \mathrm{mg} / \mathrm{Kg}$ $\left.{ }^{1}\right)$, despite the apparent stimulus, it is clear tendency in the reduction in activity $(23.0 \mathrm{nmol} / \mathrm{min} / \mathrm{mg}$ protein; $\mathrm{P}<0.05)$.
Table 2: Effect of quercetin on acetylcholinesterase activity-modulated by tamoxifen in different regions of brain

\begin{tabular}{cccc} 
Acetylcholinesterase Activity (nmol/min/mg protein) \\
\hline $\begin{array}{c}\text { Treatment } \\
\text { Group }\end{array}$ & Cerebellum & Cortex & Hippocampus \\
\hline OVXT & $34.0 \pm 2.80$ & $61.8 \pm 6.04$ & $143.0 \pm 8.99$ \\
\hline OVXTQ2.5 & $41.5 \pm 2.77$ & $45.5 \pm 16.3$ & $149.0 \pm 8.04$ \\
\hline OVXTQ7.5 & $29.0 \pm 0.57$ & $70.9 \pm 3.46$ & $103.0 \pm 10.7^{*}$ \\
\hline OVXTQ22.5 & $28.2 \pm 0.92$ & $97.2 \pm 10.6^{*}$ & $79.7 \pm 7.68^{* *}$ \\
\hline OVXTQ67.5 & $37.5 \pm 2.75$ & $84.8 \pm 3.35^{*}$ & $146.0 \pm 9.48$
\end{tabular}

OVXT - rats ovariectomized treated with tamoxifen. OVXTQ2.5 rats ovariectomized treated with tamoxifen and quercetin $2.5 \mathrm{mg} / \mathrm{Kg}$; OVXTQ7.5 - rats ovariectomized treated with tamoxifen and quercetin $7.5 \mathrm{mg} / \mathrm{Kg}$; OVXTQ22.5 - rats ovariectomized treated with tamoxifen and quercetin $22.5 \mathrm{mg} / \mathrm{Kg}$; OVXTQ67.5 - rats ovariectomized treated with tamoxifen and quercetin $67.5 \mathrm{mg} / \mathrm{Kg}$. Data represent the means \pm mean standard errors of 6 animals.

${ }^{*} \mathrm{P}<0.05 ;{ }^{* *} \mathrm{P}<0.01$.

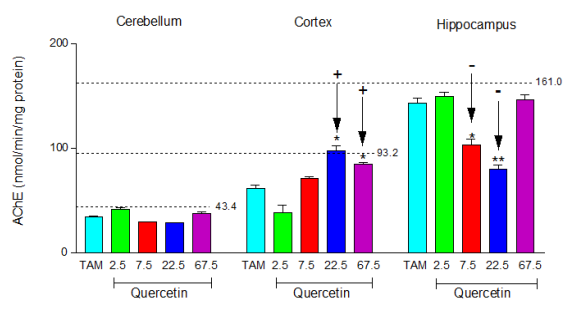

Figure 3: Effect of quercetin on acetylcholinesterase activity-modulated by tamoxifen in different regions of brain. $2.5-67.5$ dose quercetin $(\mathrm{mg} / \mathrm{Kg})$ administered in rats. Data represent the means \pm mean standard errors of 6 animals. ${ }^{*} \mathrm{P}<0.05 ;{ }^{* *} \mathrm{P}<0.01$

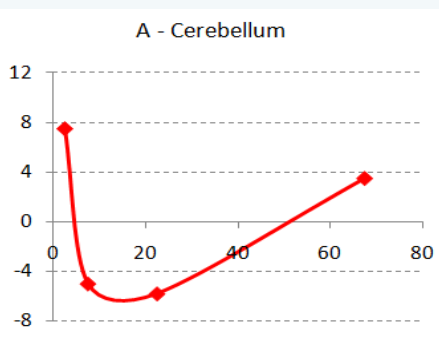

Quercetin (mg/Kg)

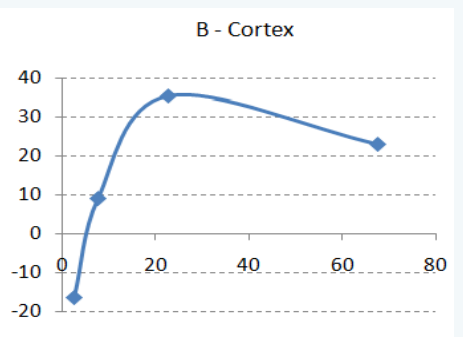

Quercetin (mg/Kg)

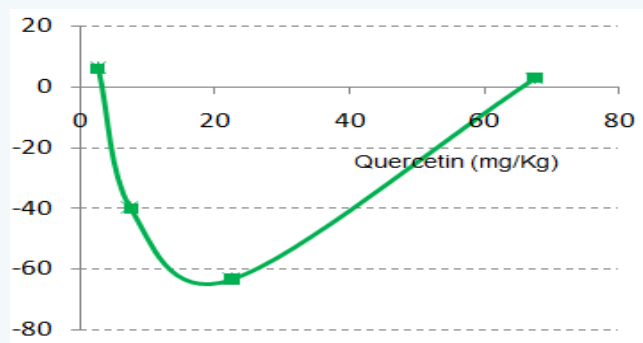

C - Hippocampus

Figure 4: Effect versus dose relationships with respect to the actions of quercetin on Acetylcholinesterase activity-modulated by tamoxifenin different regions of brain. The values represented were calculated by subtracting the activity of group tamoxifen plus quercetin $\left(O V X T Q_{2.5-}\right.$ ${ }_{67.5}$ ) of the OVXT group. A - cerebellum; B - cortex and C - hippocampus.

The same calculation of dose-effect relationship was made the other regions. It was observed in the cerebellum that although there was no statistically significant change in the activity of acetylcholinesterase of all treated groups, the dose-effect curve clearly a biphasic action of quercetin, with a U-shaped curve (4A). The same was observed in the hippocampus (4C), but with significant results. In the hippocampus, the agonist activity of tamoxifen was shown to be significantly higher when the animals were treated with quercetin in dose of 7.5 and $22.5 \mathrm{mg} /$ $\mathrm{Kg}$. With the dose of $7.5 \mathrm{mg} / \mathrm{Kg}$ dose, the activity decreased $40.0 \mathrm{nmol} / \mathrm{min} / \mathrm{mg}$ protein $(\mathrm{P}<0.05)$ being more expressive at a dose of $22.5 \mathrm{mg} / \mathrm{Kg}$, with a decrease of $63.3 \mathrm{nmol} / \mathrm{min} / \mathrm{mg}$ protein $(\mathrm{P}<0.01)$. On the other hand, the same did not occur with the other doses of quercetin $(2.5$ and $67.5 \mathrm{mg} / \mathrm{Kg})$. The values 
of the enzyme activity increased but remained very close to the animals treated with tamoxifen alone, with $149 \pm 8.04 \mathrm{nmol} /$ $\mathrm{min} / \mathrm{mg}$ protein and $146 \pm 9.48 \mathrm{nmol} / \mathrm{min} / \mathrm{mg}$ protein to 2.5 and $67.5 \mathrm{mg} / \mathrm{Kg}$ respectively. In cerebellum, the extreme doses (2.5 and $67.5 \mathrm{mg} / \mathrm{Kg}$ ) showed slight increase in the activity of acetylcholinesterase, while in other doses $(7.5$ and $22.5 \mathrm{mg} / \mathrm{Kg}$ ) decreased.

\section{Conclusion}

The major finding of the present study it that quercetin has a biphasic action interfering in the acetylcholinesterase activity-modulated by tamoxifen and this both tamoxifen as quercetin feature a particular action in each region of the brain. However, these findings may provide future studies for a better understanding of the mechanisms involved in this interaction in the brain, emphasizing the therapeutic potential of these two compounds not only in anticancer therapy as well as in neurodegenerative diseases. Besides, these data suggest attention in any therapy associated with tamoxifen.

\section{References}

1. Ping SE, Trieu J, Wlodek ME, Barrett GL (2008) Effects of estrogen on basal forebrain cholinergic neurons and spatial learning. J Neurosci Res 86(7): 1588-1598.
2. McMillan PJ, LeMaster AM, Dorsa DM (2002) Tamoxifen enhances choline acetyltransferase mRNA expression in rat basal forebrain cholinergic neurons. Brain Res Mol Brain Res 103(1-2): 140-145.

3. Abdalla FH, Cardoso AM, Schmatz R, Gonçalves JF, Baldissarelli J, et. al. (2014) Protective effect of quercetin in ecto-enzymes, cholinesterases, and myeloperoxidase activities in the lymphocytes of rats exposed to cadmium. Mol Cell Biochem 396(1-2): 201-211.

4. Jain AK, Thanki K, Jain S (2013) Co-encapsulation of tamoxifen and quercetin in polymeric nanoparticles: implications on oral bioavailability, antitumor efficacy, and drug-induced toxicity. Mol Pharmaceutics 10 (9): 3459-3474.

5. Kavithaa K, Sumathi S, Paulpandi M, Padma PR (2014) Increased anticancer efficacy by the combined administration of quercetin in multidrug resistant breast cancer cells. BMR Cancer Research 1(1): $1-13$.

6. Cimasoni G (1966) Inhibition of cholinesterase by fluoride in vitro. Biochem J 99(1): 133-137.

7. Lowry OH, Rosebrough NJ, Farr AL, Randall RJ (1951) Protein measurement with Folin phenol reagent. J BiolChem, 193(1): 265-272.

8. Ellman GL, Courtney KD, Andres V, Featherstone RM (1961) A new and rapid colorimetric determination of acetylcholinnesterase activity. Biochem Pharmacol 7(2): 88-95.

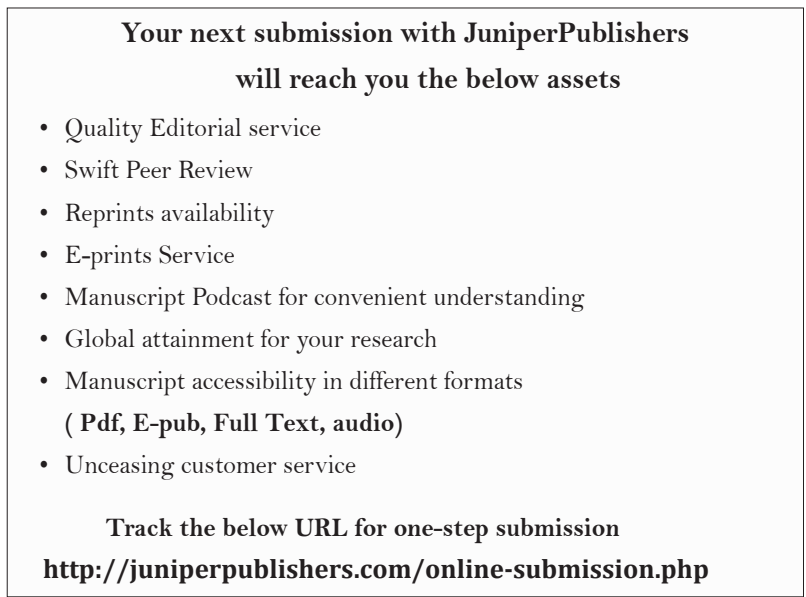

